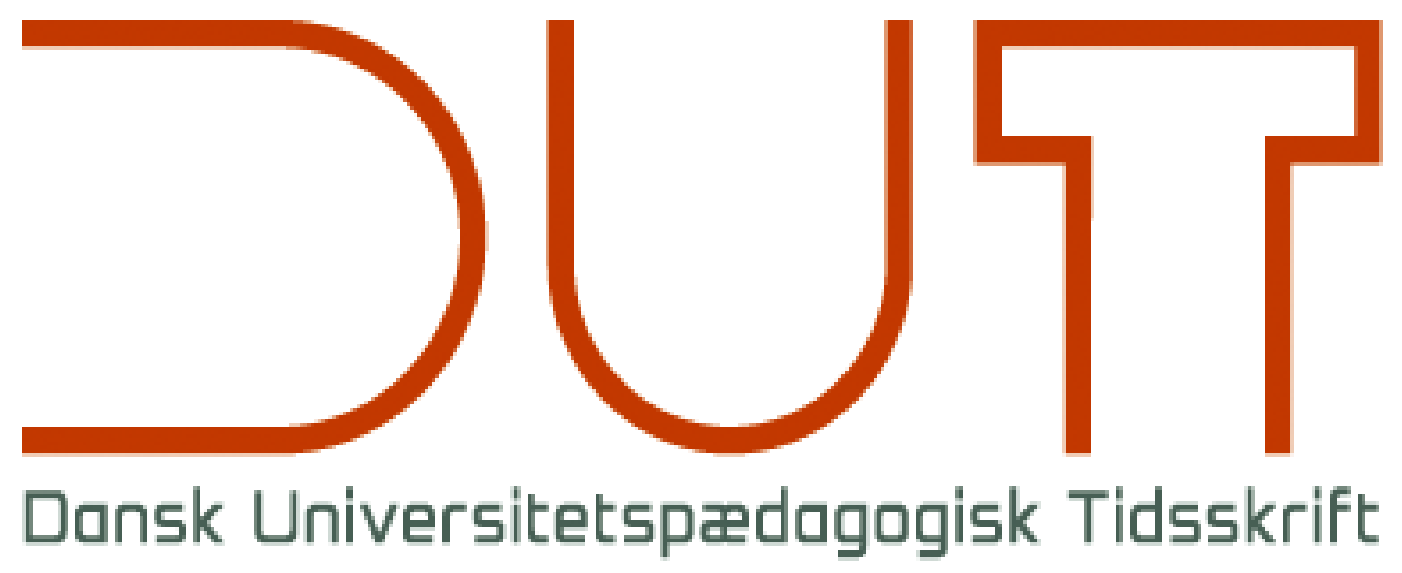

Tema

Undervisningens teknologier og teknikker

Årgang 15 nr. 28 / 2020

Titel

Betydning af individuelle faktorer for frafaldsrisiko

- en analyse af spørgeskemaer og studieadministrative data

Forfattere

Sidetal

Udgivet af

URL

Emil Smith, David Reimer, Christian Kjeldsen

$164-181$

Dansk Universitetspædagogisk Netværk, DUN

> http://dun-net.dk/

Betingelser for brug af denne artikel

(C) Copyright
Denne artikel er omfattet af ophavsretsloven, og der må citeres fra den. Følgende betingelser skal dog være opfyldt:

- Citatet skal være i overensstemmelse med "god skik"

- Der må kun citeres „i det omfang, som betinges af formålet“

- Ophavsmanden til teksten skal krediteres, og kilden skal angives ift. ovenstående bibliografiske oplysninger.

DUT og artiklens forfatter 


\title{
Betydning af individuelle faktorer for frafaldsrisiko - en analyse af spørgeskemaer og studieadministrative data
}

\author{
Emil Smith ${ }^{\mathrm{a}, 1}$, David Reimer ${ }^{\mathrm{b}}$, Christian Christrup Kjeldsen ${ }^{\mathrm{c}}$ \\ a,b,cDanmarks institut for Pædagogik og Uddannelse, Aarhus Universitet
}

Videnskabelig artikel, fagfællebedømt

\begin{abstract}
At falde fra et universitetsstudium sker $i$ en proces mellem individuelle egenskaber og mødet med uddannelsesinstitutionen. Tidligere forskning har peget på betydningen af at komme fra ikke-uddannelsesvante hjem. Dette studie undersøger, i et frafaldsperspektiv, hvad forældres uddannelsesbaggrund samt adgangsgivende karaktergennemsnit betyder for mødet med det faglige niveau og studiemiljøet - og yderligere betydningen af individuelle baggrundskarakteristika for frafaldsrisikoen generelt. På baggrund af en kombination af spørgeskemadata fra 420 frafaldne studerende samt studieadministrativt data fra 10.226 studerende, begge dele fra fakultetet Arts på Aarhus Universitet, finder vi, at der blandt frafaldne studerende er et lavere adgangsgivende karaktergennemsnit forbundet med mere negative oplevelser af det faglige niveau, samt at studerende med forældre uden længere videregående uddannelser oplever at få mindre støtte og feedback fra undervisere. Derudover finder vi, at alder, adgangsgivende karaktergennemsnit, typen af ungdomsuddannelse og antal sabbatår har relativ stor forklaringskraft for frafaldsrisiko.
\end{abstract}

\section{Indledning}

Indenfor forskning i og policy om videregående uddannelser er frafald en helt central problemstilling. Perspektiver på frafald har varieret (Aljohani, 2016a) mellem mere individorienterede psykologiske teorier (fx Astin, 1984; Bean \& Eaton, 2000) og sociologiske teorier med fokus på sociale strukturer og institutionelle forhold (fx Spady, 1970; Tinto, 1975). Samtidig har den empiriske forskning vist, hvordan frafaldsproblematikken har rødder i både individuelle og institutionelle forhold (Aljohani, 2016b; Qvortrup, Smith, Lykkegaard, \& Rasmussen, 2018). Dermed kan frafald anskues som en proces, der sker i mødet mellem uddannelsesinstitutionen og den studerende, med dennes individuelle karakteristika. Som følge af den generelle ekspansion i uddannelse (Reimer \& Pollak, 2010; Thomsen, 2015) er nye typer af studerende blevet en del af universitetets studentermasse. Dette er studerende med en anden baggrund end fortidens typiske studerende (Højbjerg \& Martinussen, 2015). Dette har givet anledning til forandringer i undervisning (se fx Biggs \& Tang, 2007), men også udfordringer relateret til frafald (Holmegaard, Madsen, \& Ulriksen, 2017). Denne udvikling giver et øget behov for viden om, hvordan den studerendes møde med institutionen har betydning for frafald, samt hvordan forskelle i studerendes baggrund har betydning for deres frafaldsrisiko.

${ }^{1}$ Kontakt: esmith@edu.au.dk 


\section{Frafald og social baggrund - ikke-uddannelsesvante studerende}

Det danske universitetslandskab har siden midten af 1960erne gennemgået en forvandlingsproces. Danske universiteter kan i dag karakteriseres som masseuniversiteter (Højbjerg \& Martinussen, 2015; Trow, 1972), hvilket har medført en stigende diversitet i studentermassen. Forandringen fra de klassiske elitære universiteter mod masseuniversiteter har medført et skel mellem de "klassiske" studerende, dvs. studerende fra hjem med universitetsuddannede forældre, og ikke-uddannelsesvante studerende, dvs. studerende hvis forældre ikke er universitetsuddannede. For ikke-uddannelsesvante studerende er uddannelse en måde at få adgang til et kompetitivt jobmarked (Thomsen, Munk, Eiberg-Madsen, \& Hansen, 2013). I international forskning omtales denne gruppe ofte som non-traditional students (O'Shea, 2016; Reay, Crozier, \& Clayton, 2010; Robinson \& Laing, 2003). Tidligere forskning har vist, hvordan studerende fra ikke-uddannelsesvante hjem kan opleve problemer i mødet med universitetet (Reay et al., 2010) og har svært ved at lære de akademiske koder (Bourdieu, 1984; M. S. Larsen, Kornbeck, Kristensen, Larsen, \& Sommersel, 2013, p. 39). Endvidere påvirker studerendes faglige niveau opfattelsen af undervisning og studiemiljø (Thingholm, Reimer, Keiding, Due, \& Smith, 2016, p. 24). I dansk kontekst har forskning vist, at studerende med arbejderklassebaggrund i mindre grad oplever at høre til på universitetet. De rapporterer i højere grad faglige problemer, og de oplever ikke, at de faglige aspekter af studiet "kommer naturligt" (Thomsen et al., 2013). Af disse årsager er denne gruppe af studerende relevante i et frafaldsperspektiv. Med et øget optag og en ændret studentermasse er det et centralt problem, hvordan tidligere faglige præstationer og social baggrund påvirker den studerendes oplevelse af det at gå på universitetet (Cotton, Nash, \& Kneale, 2017; Holmegaard et al., 2017; Lynch \& Bishop-Clark, 1998). Frafald set i sammenhængen mellem individuelle karakteristika og oplevelsen af at gå på universitetet kan derfor give indblik i mekanismer bag frafaldsprocesserne.

\section{Baggrundskarakteristika og frafald i dansk kontekst}

I en dansk sammenhæng peger forskning i frafald på, at betydningen af baggrundskarakteristika for frafald kan være anderledes for danske studerende end studerende fra øvrige lande. Blandt andet har økonomiske faktorer mindre indflydelse, grundet ikkeeksisterende studieafgifter samt SU-systemet (Troelsen \& Laursen, 2014).

Flere studier har brugt studieadministrative data til at undersøge baggrundskarakteristikas betydning for frafald, dette dog oftest på enkelte studieretninger (Bager-Elsborg, Herrmann, Troelsen, \& Ulriksen, 2019; Holm \& Rasmussen, 2016; U. Larsen, 2000; Midtiby \& Egemose, 2019; O'Neill, Christensen, Vonsild, \& Wallstedt, 2014; O'Neill, Hartvigsen, Wallstedt, Korsholm, \& Eika, 2011). Nyere undersøgelser har afdækket, at adgangsgivende karaktergennemsnit, typen af ungdomsuddannelse (EVA, 2018a) og afklaringsgraden i studievalget (EVA, 2018b) er væsentlige prædiktorer for frafald. Generelt finder studierne, at højere karaktergennemsnit, både adgangsgivende og på studiet, er forbundet med lavere frafaldsrisiko. At studerende, der kommer fra en almen gymnasial uddannelse (STX), har lavere frafaldsrisiko end studerende fra de øvrige typer af ungdomsuddannelser. Højere alder er forbundet med højere frafaldsrisiko, mens der er blandede resultater for betydningen af køn. Men da disse resultater ofte baseres på data fra enkelte studieretninger, er det relevant at efterprøve resultaterne på en bredere population af studerende. Derudover kan frafaldsforskning i dansk kontekst siges at være kendetegnet af retrospektive designs og kvalitative interviews (se fx Troelsen, 2011). Fænomenet undersøges i dybden, men fænomenets udbredelse afdækkes 
ikke i tilstrækkelig grad. Derfor kan viden om betydningen af individuelle baggrundskarakteristika for frafald siges at være mangelfuld i forhold til generalisering til studenterpopulationen. Derudover har studiemiljø og undervisning vist sig at have stor betydning for frafald (Qvortrup et al., 2018; Tinto, 2000, 2012). Derfor er sammenspillet mellem de individuelle karakteristika og de institutionelle forhold en relevant problematik.

Dermed har studiet et dobbelt fokus. For det første undersøges, i et frafaldsperspektiv, betydningen af forældres uddannelsesbaggrund og adgangsgivende karaktergennemsnit for de studerendes møde med fagligt niveau, arbejdsbyrde og studiemiljø på universitetet. Dernæst undersøges betydningen af baggrundskarakteristika for frafaldsrisikoen. Disse problematikker undersøges ud fra følgende forskningsspørgsmål:

Delspørgsmål 1:

Hvordan har individuelle karakteristika betydning for mødet med de institutionelle rammer i relation til frafald?

Delspørgsmål 2:

Hvilke individuelle karakteristika har betydning for frafald?

Artiklen struktureres efter disse to forskningsspørgsmål.

\section{Metode}

Forskningsspørgsmålene er søgt besvaret med afsæt i data om studerende på fakultetet Arts på Aarhus Universitet. Med disse studieadministrative data har vi fået mulighed for at estimere sammenhænge mellem frafald og individuelle baggrundskarakteristika. Yderligere har vi haft mulighed for at koble spørgeskemadata med studieadministrative data og derved belyse de studerendes møde med institutionen, og hvordan de individuelle baggrundskarakteristika påvirker mødet. Dette studie har dermed et robust design, da to ofte anvendte indsamlingsmetoder kombineres, nemlig retrospektivt indsamlet data og studieadministrativt data. Dette studie supplerer tidligere undersøgelser med et longitudinelt design (Willett \& Singer, 1991) og med et stort datamateriale, der dækker flere studieretninger på det humanistiske fakultet Arts ved Aarhus Universitet. Humaniora er en relevant case, der dækker over en stor diversitet i uddannelser og frafaldsrater (Aarhus Universitet, 2016a). De to forskningsspørgsmål besvares med udgangspunkt i to separate datakilder og analyser. De benævnes henholdsvis delanalyse 1 og 2.

\section{Design}

Delanalyse 1 baserer sig på en spørgeskemaundersøgelse. Studerende, som er faldet fra, er blevet bedt om at angive årsager til deres frafald. Der er således tale om et retrospektivt design, hvor vi undersøger selvrapporterede frafaldsårsager, og hvordan de relaterer sig til individuelle karakteristika, dvs. indikatorer på at være ikke-uddannelsesvant ${ }^{2}$. Vi fokuserer på

\footnotetext{
${ }^{2}$ kategorien af ikke-uddannelsesvante studerende hører også minoritetsdanskere (se fx. Hoff \& Demirtas, 2009), dog viser det sig, at datagrundlaget i spørgeskemaet er forholdsvist lille set i relation til denne gruppe af respondenter tilhørende minoritetskategorier, og der kan således ikke gennemføres statistiske analyser for gruppen på spørgeskemadata alene. Dog har vi haft mulighed for at se på betydningen for frafaldsrisiko af henholdsvis ikke at have dansk statsborgerskab eller at være af anden herkomst end dansk ved hjælp af studieadministrative data.
} 
frafaldsårsager relateret til fagligt niveau, arbejdsbyrde og studiemiljø. Som indikatorer på at være ikke-uddannelsesvanti bruger vi forældres uddannelsesbaggrund og det adgangsgivende karaktergennemsnit. Vi bringer dermed fokus på, hvordan det adgangsgivende karaktergennemsnit og forældres uddannelsesbaggrund har betydning for de studerendes svar vedrørende fagligt niveau, arbejdsbyrde og studiemiljø. Analysen udføres som en række bivariate analyser.

Delanalyse 2 baserer sig på såkaldt time-to-event data, dvs. vi følger de studerende fra indskrivningstidspunktet til enten frafald eller gennemførsel og har tidsangivelser (dato) for indskrivning samt frafald eller gennemførsel. Data er udtrukket fra Aarhus Universitets studieadministrative system (STADS). Her undersøger vi en række individuelle baggrundsfaktorers betydning for frafaldsrisiko i en samlet multivariat analyse.

\section{Deltagere}

Delanalyse 1 baserer sig på data fra spørgeskemaer indsamlet i forbindelse med en intern undersøgelse af frafaldsårsager blandt bachelorstuderende på fakultetet Arts ved Aarhus Universitet (Aarhus Universitet, 2016a). Data består således af spørgeskemadata fra 420 bachelorstuderende på Arts fakultetet, der er faldet fra i perioden 1.1.2014- 1.7.2015.

Delanalyse 2 er baseret på studieadministrative data fra samtlige bachelorstuderende på Arts, optaget i perioden 01.03.2010-18.09.2015. Data indbefatter 10.672 studerende.

\section{Dataindsamling}

Spørgeskemaundersøgelsen, som ligger til grund for delanalyse 1, blev gennemført ved internet-besvarelser og telefoninterviews. Ud af 1035 frafaldne studerende svarede 505, resulterende i en svarprocent på 49. Grundet manglende svar på enkelte spørgsmål er den analytiske stikprøve på 420 studerende. Besvarelserne er koblet sammen med udtræk fra det studieadministrative system (STADS).

\section{Instrument}

Delanalyse 1 baserer sig på et spørgeskema konstrueret af en konsulentvirksomhed for Aarhus Universitet med input fra faglitteratur samt eksperter (Aarhus Universitet, 2016a). Spørgeskema-spørgsmålene belyser, hvilken betydning forskellige årsager har for frafaldet.

Vi analyserer følgende udsagn om årsager til frafald fra spørgeskemaet:

- $\quad$ Det faglige niveau på uddannelsen var for højt

- Jeg vurderede, at jeg ikke var lige så dygtig som mine studiekammerater

- Det var vanskeligt for mig at overskue maengden af studiearbejde

- Uddannelsen kraevede for meget tid

- Jeg manglede støtte og feedback fra underviserne

- Jeg manglede støtte og feedback fra mine medstuderende

\section{Variable}

I delanalyse 1 måler vi forældres uddannelsesbaggrund som det højeste uddannelsesniveau blandt forældreparret, opdelt i tre kategorier: Lang videregående uddannelse (kandidatniveau eller over), mellemlang videregående uddannelse (bachelor og professionsbachelor eller tilsva- 
rende) og $a$ det $^{3}$. Det adgangsgivende karaktergennemsnit er målt på en kontinuert skala gående fra 2 til 12. De afhængige variable i delanalyse 1 er de studerendes svar på de ovennævnte udsagn. Vurderingen sker på en 5-punkts likert-skala, omkodet til tre kategorier: 1. Meget høj/høj grad 2. Nogen grad 3. Mindre grad/Slet ikke.

I delanalyse 2 indgår status som afhængig variabel. Status er en nominal variabel, hvor 1 angiver, at den studerende er faldet fra, 2 at den studerende har afsluttet sin uddannelse, og 3 at den studerende stadig er indskrevet. Alder, køn, adgangsgivende karaktergennemsnit, antal sabbatår, ungdomsuddannelse, statsborgerskab og herkomst ${ }^{4}$ indgår som uafhængige variable. Endvidere kontrolleres for, hvilket af de tre institutter på Arts den studerende har været indskrevet på. Alder er målt i kategorierne 18-25, 26-33, 34-40 og over 40 år. Køn er en dikotom variabel, hvor 1 angiver mand og 0 angiver kvinde. Adgangsgivende karaktergennemsnit er målt som i delanalyse 1. Ungdomsuddannelse er målt ved en dikotom variabel, hvor 1 angiver, at den studerende har en STX, og 0 angiver øvrige typer ungdomsuddannelser $^{5}$. Statsborgerskab og herkomst er ligeledes dikotome variable, hvor 1 angiver dansk statsborgerskab, og 0 angiver øvrige typer statsborgerskab. Institut er angivet ved tre dikotome variable, der angiver, om den studerende tilhører det pågældende institut.

Forud for den endelige delanalyse 2 har vi også testet for geografisk afstand fra ungdomsuddannelsesstedet til Aarhus Universitet, ansøgningsprioritet, kvotenummer og karaktergennemsnit på universitetet. For mange studerende manglede der dog data for ungdomsuddannelsesstedet, ansøgningsprioritet og kvotenummer, hvorfor de måtte udelades af den endelige model. Karaktergennemsnit på universitetet manglede ligeledes for mange studerende, især for dem, der faldt fra tidligt eller ikke har været indskrevet længe nok til at få tildelt karakterer.

\section{Analyser}

For i delanalyse 1 at afdække betydningen af såvel forældres uddannelsesbaggrund som de studerendes karaktergennemsnit fra adgangsgivende ungdomsuddannelse bruges disse som uafhængige variable og holdes op imod de angivne frafaldsårsager. Analyserne er udført ved one-way ANOVA og krydstabuleringer, der er signifikanstestet med Pearsons $\chi^{2}$. Der er udført analyser på samtlige spørgsmål, men kun de statistisk signifikante resultater på et 95\%niveau $(\alpha=0,05)$ præsenteres. Da vi udfører flere bivariate analyser, foretages såkaldt bonferroni justering for at undgå type l-fejl, dvs. at det reelle signifikansniveau er 99,992\% $(a=0,008)^{6}$. Ikke-signifikante forskelle og sammenhænge betyder ikke nødvendigvis, at denne ikke findes, men blot at den er af en størrelse eller ved tilfældig variation, der gør at den ikke er forekommet i denne stikprøve. Cohens $f$ rapporteres for at angive effektstørrelse (Cohen, 1988, p. 273). Missing data er behandlet ved såkaldt 'listwisedeletion', dvs. respondenter med manglende besvarelser er udeladt af analyserne.

\footnotetext{
${ }^{3}$ Herunder grundskole, erhvervsuddannelser, teknisk skole, studentereksamen og kort videregående uddannelse som den højeste gennemførte uddannelse.

${ }^{4}$ Herkomst er ikke registreret i det studieadministrative data, men er manuelt tilføjet ved studerende, som havde både udenlandske for- og efternavne.

${ }^{5}$ Herunder HF, HHX, HTX, IB, udenlandske eksamener samt særlige ungdomsuddannelser (fx Rudolf Steiner-skoler).

${ }^{6}$ Da vi tester for hver af de seks items, dividerer vi den oprindelige a med seks
} 
I delanalyse 2 behandles de studieadministrative data som time-to-event data (se fx Chimka, Reed-Rhoads, \& Barker, 2007) for at vurdere betydningen af baggrundsfaktorer for frafald. Således behandles frafald (ja/nej) som et spørgsmål i en multipel cox-regression (proportional hazards regression) (Bradburn, Clark, Love, \& Altman, 2003; Cox, 1972), der modellerer variables påvirkning på et udfald over tid. Det muliggør udregning af estimater af de forstærkende eller formindskende påvirkninger, de forskellige variable har på frafaldsrisikoen. Desuden tillader cox-regressionen at arbejde med højre 'censureret' data. Det vil sige at inkludere studerende i analysen, som hverken har afsluttet eller er faldet fra deres uddannelse. Derudover giver cox-regressionen mulighed for at arbejde med venstre 'trunkering', altså arbejde med studerende med forskellige indskrivningstidspunkter, således at den tid, de studerende er studieaktive, udregnes fra deres individuelle indskrivningstidspunkt. Modellens standardfejl er justeret for, at de studerende er grupperet i uddannelser. Af de 10.672 studerende manglede der data for en eller flere variable for 446 af dem. Den analytiske sample er derfor på 10.226 studerende.

Alle analyser er udført i statistiksoftwarepakken Stata 15.

\section{Resultater}

Resultatafsnittet er opdelt efter delanalyse 1 og 2 . Under delanalyse 1 præsenteres først forskelle i adgangsgivende karaktergennemsnit på de udvalgte spørgeskema-items; dernæst præsenteres sammenhænge mellem forældres uddannelsesbaggrund og de udvalgte items. Endelig præsenteres resultaterne fra delanalyse 2 .

\section{Delanalyse 1 - Bivariate analyser}

I tabel 1 præsenteres deskriptiv statistik for datagrundlaget i delanalyse 1. For adgangsgivende karaktergennemsnit er angivet gennemsnit og standardafvigelse, mens der for de kategoriale variable, som angiver forældres uddannelsesniveau, er angivet frekvenser.

Tabel 1. Deskriptiv statistik - spørgeskemadata

\begin{tabular}{|c|c|c|c|c|}
\hline Variabel & Gennemsnit/frekvens & $\begin{array}{l}\text { Std. afvi- } \\
\text { gelse }\end{array}$ & Min. & Maks. \\
\hline $\begin{array}{l}\text { Adgangsgivende } \\
\text { karaktergennemsnit }\end{array}$ & 7,33 & 1,93 & 2 & 12 \\
\hline \multicolumn{5}{|l|}{ Foroeldres uddannel- } \\
\hline \multicolumn{5}{|l|}{ se } \\
\hline $\begin{array}{l}\text { Mellemlang videre- } \\
\text { gående uddannelse }\end{array}$ & 0,34 & & 0 & 1 \\
\hline $\begin{array}{l}\text { Lang videregående } \\
\text { uddannelse }\end{array}$ & 0,28 & & 0 & 1 \\
\hline$\varnothing$ vrig uddannelse & 0,38 & & 0 & 1 \\
\hline$N$ & 467 & & & \\
\hline
\end{tabular}


Først præsenteres resultaterne af de bivariate analyser af sammenhængen mellem de studerendes besvarelser og henholdsvis karaktergennemsnit og forældres uddannelse. Herefter præsenteres resultaterne af cox-regressions-modellen, der viser sammenhængen mellem forskellige baggrundskarakteristika og frafald i en samlet model.

\section{Adgangsgivende karaktergennemsnit}

Tabel 2 angiver resultaterne af one-wayANOVA-testene for forskelle i adgangsgivende karaktergennemsnit for de forskellige svarkategorier i de udvalgte items. Der er statistisk signifikante forskelle $\mathrm{i}$ adgangsgivende karaktergennemsnit blandt studerende med forskellige vurderinger af det faglige niveau og opfattelsen af egne faglige evner.

Tabel 2. ANOVA-test af forskelle i adgangsgivende karaktergennemsnit.

\begin{tabular}{|c|c|c|c|c|c|c|}
\hline Item & Svar & $\begin{array}{l}\text { Gen- } \\
\text { nemsnit }\end{array}$ & $\begin{array}{l}\text { Std. afvi- } \\
\text { gelse }\end{array}$ & $\mathrm{N}$ & $\begin{array}{l}\text { P- } \\
\text { værdi }\end{array}$ & $\begin{array}{l}\text { Co- } \\
\text { hen's f }\end{array}$ \\
\hline \multirow{4}{*}{$\begin{array}{l}\text { Det faglige } \\
\text { niveau var for } \\
\text { højt }\end{array}$} & Meget høj/høj grad & 6,80 & 2,00 & 33 & & \\
\hline & Nogen grad & 6,78 & 2,24 & 60 & & \\
\hline & Mindre grad/slet ikke & 7,57 & 1,76 & 32 & 0,002 & 0,17 \\
\hline & & & & 7 & 0 & \\
\hline \multirow{4}{*}{$\begin{array}{l}\text { Jeg vurderede, } \\
\text { at jeg ikke var } \\
\text { lige så dygtig } \\
\text { som mine med- } \\
\text { studerende }\end{array}$} & Meget høj/høj grad & 6,51 & 2,15 & 56 & & \\
\hline & Nogen grad & 7,11 & 2,21 & 73 & & \\
\hline & Mindre grad/slet ikke & 7,63 & 1,67 & 29 & 0,000 & 0,331 \\
\hline & & & & 1 & 1 & \\
\hline
\end{tabular}

Tabel 2 viser, at studerende, der opfatter det faglige niveau som værende for højt, i gennemsnit har et lavere adgangsgivende karaktergennemsnit end de studerende, som svarer $i$ mindre grad/slet ikke. Der ses her et helt karakterpoints forskel mellem de to yderste grupper. De studerendes faglige præstationer på den adgangsgivende uddannelse har dermed betydning for vurderingen af det faglige niveau. Effektstørrelsen 0,17 angiver, at der er tale om en lille forskel.

Derudover ses en statistisk signifikant forskel i adgangsgivende karaktergennemsnit afhængigt af studerendes opfattelse af egne evner sammenlignet med deres medstuderende. Her ses en større forskel mellem de to yderste grupper. Studerende, der erklærer sig 'i mindre grad' eller 'slet ikke' enig, har ca. 1,1 point højere adgangsgivende karaktergennemsnit end de studerende, der erklærer sig i 'meget høj' eller 'høj grad' enig. Effektstørrelsen 0,33 angiver, at der er tale om en moderat forskel.

Samlet set synes studerende med en mere negativ opfattelse af det faglige niveau i gennemsnit at have lavere adgangsgivende karaktergennemsnit. Mindre fagligt stærke studerende, som falder fra, falder altså i højere grad fra af faglige årsager. 


\section{Forceldres uddannelsesbaggrund}

Kun i et enkelt tilfælde havde de studerendes besvarelser statistisk signifikant sammenhæng med deres forældres uddannelsesbaggrund. Dermed hænger oplevelsen af fagligt niveau, arbejds- og tidspres, eller støtte fra medstuderende ikke umiddelbart sammen med, om man kommer fra ikke-uddannelsesvante hjem. Det tyder på, at frafald blandt studerende fra ikkeuddannelsesvante hjem ikke skyldes disse faktorer.

Figur 1 viser dog en statistisk signifikant sammenhæng mellem forældres uddannelsesbaggrund og oplevelse af støtte og feedback fra undervisere. Studerende med forældre med en lang videregående uddannelse oplever i mindre grad at mangle støtte og feedback fra undervisere end de øvrige grupper. Således svarer 16,3\% flere studerende med forældre med en lang videregående uddannelse, at de i mindre grad/slet ikke manglede støtte og feedback fra underviserne end studerende, hvis forældre hverken har mellemlang eller lang videregående uddannelse. Dermed har studerende fra gruppen ' $\varnothing$ vrige uddannelser' større tendens til at erklære sig enige i, at de manglede støtte og feedback fra underviserne, end de to resterende grupper. Overordnet antyder figur 1, at oplevelsen af støtte og feedback fra undervisere afhænger af forældrenes uddannelsesbaggrund. Cramers V på 0,13 angiver, at der er tale om en mindre sammenhæng.

Figur 1. Sammenhængen mellem forældres uddannelsesbaggrund og oplevelsen af støtte og feedback fra undervisere

Jeg manglede støtte og feedback fra underviserne

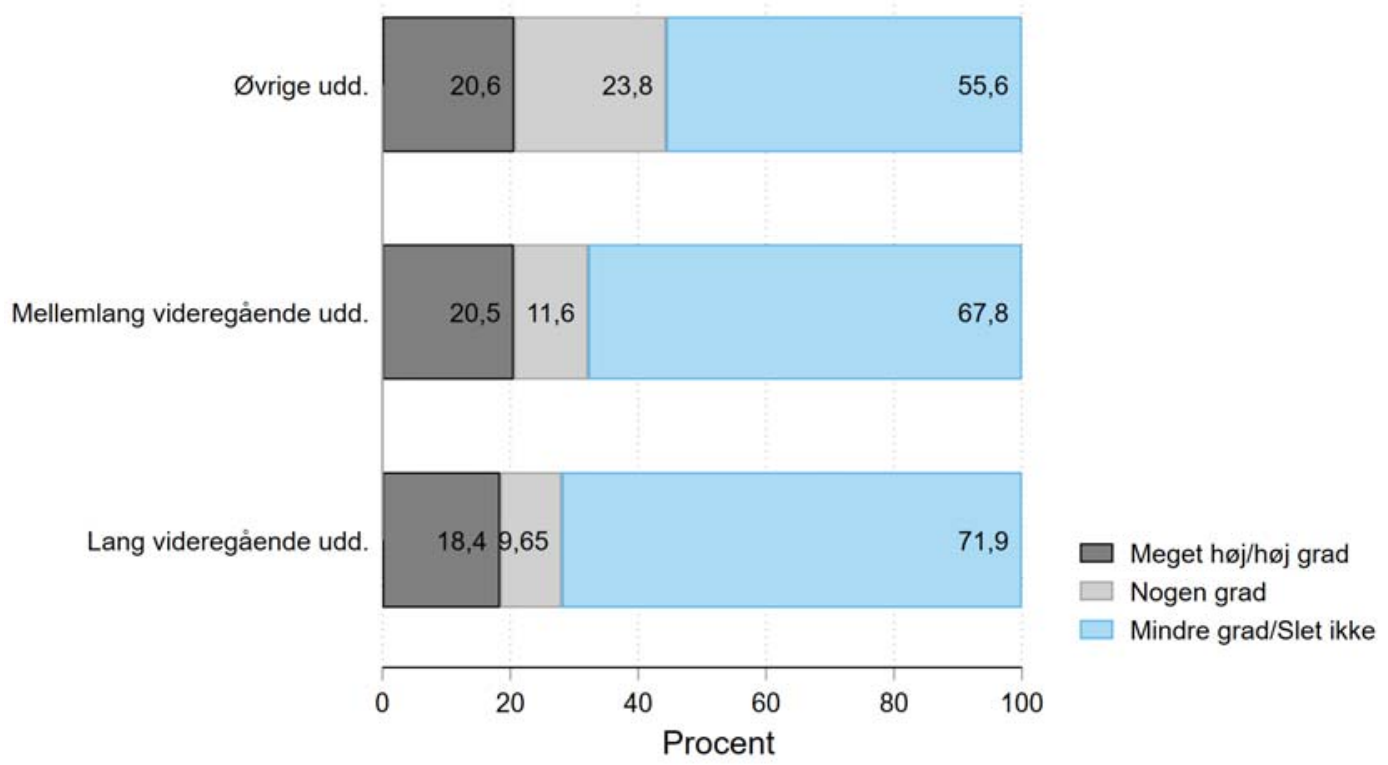

Note: $\mathrm{N}=420, \mathrm{Chi}^{2}=14,16, \mathrm{p}$-værdi 0,007, Cramers V $=0,13$

De bivariate analyser af spørgeskemabesvarelserne viste statistisk signifikante forskelle i adgangsgivende karaktergennemsnit ud fra de studerendes oplevelse af det faglige niveau, og at forældres uddannelsesbaggrund har betydning for oplevelsen af støtte og feedback fra undervisere. 
I det følgende afsnit rapporteres resultaterne fra delanalyse $2 \mathrm{i}$ form af den multiple coxregressions-analyse.

\section{Delanalyse 2 - Cox-regressionsmodel}

I tabel 3 præsenteres deskriptiv statistik for datagrundlaget i delanalyse 2. Tilsvarende tabel 1 er der for de kontinuerte variabel angivet gennemsnit og standardafvigelse, mens der for de kategoriale er angivet frekvenser.

Tabel 3. Deskriptiv statistik - studieadministrative data

\begin{tabular}{|c|c|c|c|c|}
\hline Variabel & Gennemsnit/frekvens & $\begin{array}{l}\text { Std. afvi- } \\
\text { gelse }\end{array}$ & Min. & ks. \\
\hline Alder & 22,21 & 4,85 & 18 & 75 \\
\hline \multicolumn{5}{|l|}{ Alder-kategori } \\
\hline 18-25 år & 0,92 & & 0 & 1 \\
\hline 26-33 år & 0,06 & & 0 & 1 \\
\hline 34-40 år & 0,01 & & 0 & 1 \\
\hline 41 år og ældre & 0,02 & & 0 & 1 \\
\hline Mand & 0,37 & & 0 & 1 \\
\hline Kvinde & 0,43 & & 0 & 1 \\
\hline Dansk statsborger & 0,97 & & 0 & 1 \\
\hline Andet statsborgerskab & 0,03 & & 0 & 1 \\
\hline Dansk herkomst & 0,98 & & 0 & 1 \\
\hline $\begin{array}{l}\text { Anden herkomst end } \\
\text { dansk }\end{array}$ & 0,02 & & 0 & 1 \\
\hline $\begin{array}{l}\text { Adgangsgivende karak- } \\
\text { tergennemsnit }\end{array}$ & 7,75 & 1,84 & 2 & 12.2 \\
\hline STX & 0,69 & & 0 & 1 \\
\hline $\begin{array}{l}\emptyset \text { vrige adgangsgivende } \\
\text { udd. }\end{array}$ & 0,31 & & 0 & 1 \\
\hline Sabbatår & 2,41 & 4,30 & 0 & 58 \\
\hline \multicolumn{5}{|l|}{ Institut } \\
\hline DPU & 0,12 & & 0 & 1 \\
\hline IKK & 0,49 & & 0 & 1 \\
\hline IKS & 0,39 & & 0 & 1 \\
\hline N & 10.226 & & & \\
\hline
\end{tabular}


Tabel 4 viser resultaterne for frafald fra Cox-regressionsmodellen. Koefficienterne er angivet som såkaldte hazard ratioer (se Bradburn et al., 2003). En hazard ratio større end 1 indikerer en stigning i frafaldsrisikoen. Analysen er udført i to trin - et trin, der undersøger individuelle karakteristika uafhængigt af ungdomsuddannelse, og et trin, der undersøger variable relateret til ungdomsuddannelsen. Variablene introduceres trinvist, så det kan aflæses, hvilken påvirkning, de har relateret til ungdomsuddannelsen for forholdet mellem frafald og alder, køn, statsborgerskab og herkomst. Model 1 består af alder, køn, statsborgerskab og herkomst, mens model 2 introducerer adgangsgivende karaktergennemsnit, typen af ungdomsuddannelse og antal sabbatår. Begge modeller er kontrolleret for forskelle på institutniveau ved at inddrage dikotome variable, der angiver de to institutter Danmarks institut for Pædagogik og Uddannelse (DPU) og Institut for Kultur og Kommunikation (IKK) med Institut for Kultur og Samfund (IKS) som referencegruppe. Primært vil resultaterne fra model 2 blive fortolket, da sammenhængene her er kontrolleret for samtlige af de øvrige variable.

Alder har en ikke-lineær negativ sammenhæng med vedholdenhed på studiet. Den fulde model viser, at aldersgruppen 25-33 år har en 22,6\% højere risiko for frafald ift. de 18-25 årige, mens de 33-40 årige og 41+ årige har en henholdsvis $81 \%$ og 133,8\% højere risiko. Det vil sige, at de 25-33 årige, 33-40 årige og 41+ årige har henholdsvis 1,226; 1,810 og 2,338 gange højere risiko for frafald end de 18-25 årige. Det viser, at jo ældre en studerende er ift. den yngste gruppe, hvori gennemsnitsalderen på 22 år er repræsenteret, jo større er risikoen for frafald.

Ifølge model 1 har mænd en statistisk signifikant større frafaldsrisiko end kvinder på 15,1\%. Den sammenhæng forsvinder dog, når der kontrolleres for variablene, der repræsenterer deres adgangsgivende ungdomsuddannelser. Kvinderne i undersøgelsen har i gennemsnit et adgangsgivende karaktergennemsnit, der er 0,58 karakterer højere end mændenes ${ }^{7}$. Kønsforskellen, der ses i model 1, forklares af, at kvinder har et højere adgangsgivende karaktergennemsnit end mænd generelt.

At have dansk statsborgerskab har ikke en statistisk signifikant betydning for risikoen for frafald. De udenlandske studerende har altså den samme frafaldsrisiko som studerende med dansk statsborgerskab. Tilsvarende er der ingen statistisk signifikant forskel i frafaldsrisiko mellem studerende med anden herkomst og de øvrige studerende.

Det adgangsgivende karaktergennemsnit sænker risikoen for frafald med $11,6 \%$ for hver karakterpoint højere, gennemsnittet er. Dermed har fagligt stærkere studerende, ikke overraskende, lavere frafaldsrisiko.

En almen gymnasial uddannelse, STX, sænker ligeledes risikoen for frafald med 31\%. Det vil sige, at studerende med andre typer ungdomsuddannelser har større risiko for frafald. Mulige forklaringer herpå præsenteres i diskussion.

For hvert sabbatår, den studerende har haft inden studiet, sænkes frafaldsrisikoen med $2,8 \%$. Dette er vel at mærke efter at have kontrolleret for alder, da flere sabbatår nødvendigvis er forbundet med højere alder. En pause mellem adgangsgivende og videregående uddannelse mindsker dermed risikoen for frafald.

\footnotetext{
${ }^{7}$ Statistisk signifikant på 99,999\% niveau, ved oneway ANOVA. Dette gælder både for den samlede gruppe og for de
} frafaldne. 
Når man kontrollerer for alder, køn, statsborgerskab, etnicitet, adgangsgivende karaktergennemsnit, ungdomsuddannelse og sabbatår, har studerende fra DPU en frafaldsrisiko, der er $21 \%$ lavere end den for studerende fra IKS. Studerende fra IKK er ikke signifikant forskellige fra IKS-studerende med hensyn til frafald. Når man vurderer forskellen mellem institutterne på Arts, bør man tage i betragtning, at de DPU-studerende, der deltager i denne undersøgelse, alene er studerende fra uddannelsesvidenskab. Undersøgelsen omfatter kun bachelorstuderende, og uddannelsesvidenskab er den eneste bacheloruddannelse på DPU. Mulige frafaldsforskelle mellem de enkelte uddannelser på IKS og IKK vil ikke kunne aflæses i denne analyse ${ }^{8}$. Graden af forklaret varians er udtrykt ved Somers D. Her viser model 2 sig at være en væsentlig forbedring af model 1 ved at forklare ca. dobbelt så meget varians i den afhængige variabel. Dette indikerer, at variablene relateret til adgangsgivende uddannelser, introduceret i model 2, har betydelig indflydelse på frafaldsrisikoen.

8 På mange af studierne var der for få studerende til at opnå pålidelige resultater, derfor analyseres der på institutniveau. 
Tabel 4. Cox-regressions modeller af frafald

\begin{tabular}{|c|c|c|}
\hline & Model 1 & Model 2 \\
\hline \multicolumn{3}{|l|}{ Alder: } \\
\hline \multirow[t]{2}{*}{ 26-33 år ${ }^{1}$} & $1,443^{\star \star \star}$ & $1,226^{* *}$ \\
\hline & $(0,095)$ & $(0,086)$ \\
\hline \multirow[t]{2}{*}{ 34-40 år ${ }^{1}$} & $1,763^{* * *}$ & $1,810^{\star \star \star}$ \\
\hline & $(0,178)$ & $(0,217)$ \\
\hline \multirow[t]{2}{*}{41 år og ældre ${ }^{1}$} & $1,553^{\star * *}$ & $2,338^{* \star *}$ \\
\hline & $(0,200)$ & $(0,290)$ \\
\hline \multirow[t]{2}{*}{ Mand } & $1,151^{*}$ & 1,050 \\
\hline & $(0,072)$ & $(0,061)$ \\
\hline \multirow[t]{2}{*}{ Dansk statsborger } & 1,016 & 0,808 \\
\hline & $(0,099)$ & $(0,090)$ \\
\hline \multirow[t]{2}{*}{ Anden herkomst } & 1,081 & 0,920 \\
\hline & $(0,140)$ & $(0,106)$ \\
\hline \multirow[t]{2}{*}{ Adgangsgivende karaktergns. } & & $0,884^{\star * \star}$ \\
\hline & & $(0,015)$ \\
\hline \multirow[t]{2}{*}{ STX } & & $0,690^{\star * \star}$ \\
\hline & & $(0,038)$ \\
\hline \multirow[t]{2}{*}{ Antal sabbatår } & & $0,972^{\star \star \star}$ \\
\hline & & $(0,006)$ \\
\hline \multirow[t]{2}{*}{$\mathrm{DPU}^{2}$} & $0,860^{*}$ & $0,790^{\star \star \star}$ \\
\hline & $(0,063)$ & $(0,038)$ \\
\hline \multirow[t]{2}{*}{$\mathrm{IKK}^{2}$} & 0,810 & 0,858 \\
\hline & $(0,092)$ & $(0,077)$ \\
\hline Observationer & 10226 & 10226 \\
\hline Frafaldne & 3005 & 3005 \\
\hline Somers D & 0,095 & 0,191 \\
\hline
\end{tabular}

Standardfejl, justeret for clustering i parenteser ${ }^{*} p<0.05,{ }^{* *} p<0.01,{ }^{* * *} p<0.001$

${ }^{1}$ Referencekategori 18-25 år ${ }^{2}$ Referencekategori IKS 


\section{Diskussion og konklusion}

Resultaterne fra delanalyse 1 tegner et samlet billede af, at studerende, der har mindre fagligt stærke forudsætninger med fra ungdomsuddannelsen, som falder fra, udtrykker at have sværere ved det faglige på studiet. Resultatet er ikke overraskende, men understreger, at denne gruppe studerende falder fra af mindre frivillige grunde end eksempelvis studerende, der skifter på grund af manglende interesse. Samtidig forklarer denne sammenhæng også nogle af de bagvedliggende mekanismer i sammenhængen mellem adgangsgivende karaktergennemsnit og frafaldsrisiko, der blev vist i cox-regressions-analysen, og som tidligere dansk frafaldsforskning også har vist (Holm \& Rasmussen, 2016; U. Larsen, 2000; O'Neill et al., 2014, 2011).

Derimod synes forældrenes uddannelse ikke at have betydning for opfattelsen af det faglige niveau blandt de frafaldne studerende. Det er dog et interessant fund, at studerende fra ikke-uddannelsesvante hjem oplever at få mindre støtte og feedback fra deres undervisere. En plausibel forklaring på denne sammenhæng er, at denne gruppe af studerende oplever at få mindre støtte og feedback, da den gives på en form som disse studerende ikke genkender, fordi de ikke har lært at afkode omgangsformen på universitetet (M. S. Larsen et al., 2013, p. 39). Dette stemmer overens med forskning på grundskoleområdet, som indikerer, at elever med højere socioøkonomisk baggrund oplever mere faciliterende feedback end deres klassekammerater med lavere socioøkonomisk baggrund (Sortkær, 2019). Endelig er der den mulighed, at denne gruppe af studerende har en anden forventning til eller behov for støtte og feedback end den, der gives på universitetet, i forhold til praksis på den adgangsgivende uddannelse (McQueen, 2009).

Resultaterne fra delanalyse 2 stemmer i høj grad overens med tidligere forskning. Typen af ungdomsuddannelse er flere gange blevet forbundet til forskelle i frafaldsrisiko (M. S. Larsen et al., 2013, p. 126). Da type af ungdomsuddannelse typisk er brugt som en kontrolvariabel, er der ofte ikke teoretiske forklaringer på, hvorfor den hænger sammen med frafald. Overordnet kan vi tale om to typer af mulige bagvedliggende mekanismer. For det første selektionseffekter, eksempelvis påviser Jæger \& Holm (2007) hvordan elever med højere kulturel kapital generelt vælger gymnasiale uddannelser. For det andet kvalitative forskelle i den adgangsgivende uddannelse, både Tinto (1975) og Bean (1990) taler eksempelvis om betydningen af henholdsvis prior schooling og college preparatory curriculum, der har betydning for, hvor godt nye studerende er klædt på til universitetet. Hvilken mekanisme, der gør sig gældende, er ikke muligt at afgøre ud fra dette datagrundlag. Den positive sammenhæng mellem sabbatår og vedholdenhed skyldes formentlig en større grad af afklaring omkring studievalget, hvilket flugter med tidligere resultater (Aarhus Universitet, 2016b, p. 46). Alder synes tydeligt at hænge sammen med frafald, jo ældre en studerende er, jo større er risikoen for frafald. Det kan skyldes problemer med social integration (O'Shea, 2016, p. 76; Tinto, 1975), eller at ældre studerende ofte har andre forpligtelser, der trækker i andre retninger end studiet (Robinson \& Laing, 2003). Endelig påpeger resultaterne fra coxregressionen vigtigheden i robuste metoder i spørgsmål om frafald, både i forskning og på institutionelt niveau. Således viser den først observerede sammenhæng mellem køn og frafald ikke at holde stik. Derudover viser forskellene mellem de undersøgte institutter at ændre sig ved introduktionen af flere variable. Dette understreger vigtigheden af at tage højde for baggrundskarakteristika for de studerende, der bliver rekrutteret, hvis frafaldsprocenter skal sammenlignes mellem institutter eller studier. 
Nærværende studie giver også anledning til en række metodiske refleksioner. Særligt brugen af spørgeskemadata indebærer en række begrænsninger for analyserne og de afledte resultater. Den retrospektive dataindsamling medfører validitetsproblemer, da de studerendes svar kan være underlagt efterrationaliseringer og recall-bias (Dex, 1995). Derudover er det, selvom svarprocenten er acceptabel, sandsynligt, at tilbøjeligheden til at svare på spørgeskemaet ikke har været uafhængig af for eksempel social baggrund, hvilket har konsekvenser for generaliserbarheden af resultaterne. Omvendt er det studieadministrative data af høj kvalitet, med præcise informationer og en komplet population af studerende og dermed fri for non-response, som ofte kan være et problem i studier af frafald. Begrænsningen i denne type data er dog, at mere komplicerede teoretiske konstrukter ikke kan undersøges. Til trods for dette viser vores model en ganske acceptabel forklaringskraft, idet ca. 19\% af variationen i frafald bliver forklaret af de uafhængige variable. Endelig er vores population udelukkende studerende på humaniora; det er muligt at mødet mellem studerende fra ikkeuddannelsesvante hjem og institutioner er sammensat forskelligt på andre fakulteter - eksempelvis på naturvidenskabelige uddannelser, hvor fx læringsmål kan være mere konkrete. Studiet påpeger således også de lav-praktiske og metodiske problematikker i spørgeskemaundersøgelser af frafald. Lave svarprocenter grundet i det forhold, at respondenterne ganske enkelt er sværere at få fat på, efter de har forladt studiet, ligesom de validitetsproblemer, der er forbundet med retrospektiv dataindsamling. Derfor anbefaler vi videre forskning og interne undersøgelser at foretage spørgeskemaundersøgelser løbende frem for retrospektivt. ${ }^{9}$

Overordnet giver resultaterne indblik i mekanismer bag frafald hos studerende med lavere adgangsgivende karaktergennemsnit og studerende fra ikke-uddannelsesvante hjem. For den førstnævnte gruppe studerende relaterede disse sig primært til det faglige niveau og arbejdsbyrden. For studerende fra ikke-uddannelsesvante hjem relaterede mekanismerne sig til oplevelsen af støtte og feedback fra undervisere, hvilket kan skyldes en fremmedhed overfor universitetet (Thomsen et al., 2013), og at disse studerende har sværere ved at afkode omgangsformen på universitetet (M. S. Larsen et al., 2013, p. 39). Samtidig viser resultaterne fra cox-regressionen, at mange baggrundsfaktorer har betydning for risikoen for frafald. Højere alder har en negativ betydning, hvilket flugter fint med resultater fra tidligere forskning (Bager-Elsborg et al., 2019; Holm \& Rasmussen, 2016; U. Larsen, 2000; O'Neill et al., 2014, 2011). Derudover viser resultaterne, i overensstemmelse med anden forskning, at en række forhold relateret til den adgangsgivende uddannelse også har betydning, både i form af adgangsgivende karaktergennemsnit (EVA, 2018a), type af ungdomsuddannelse (O'Neill et al., 2014) og antallet af sabbatår (M. S. Larsen et al., 2013, p. 134).

Nærværende studier bidrager til at understrege vigtigheden i, at uddannelsesinstitutioner er opmærksomme på, at studerende møder universitetet med forskellig baggrund, og at denne forskellighed kan have betydning for uddannelsessucces, eksempelvis i form af frafald. Dette kommer både til udtryk ved forskel i frafaldsrisiko afhængigt af alder og faktorer relateret til den adgangsgivende uddannelse samt forskelle i oplevelsen af fagligt niveau og støtte og feedback afhængigt af adgangsgivende karaktergennemsnit og forældres uddannelsesniveau. Derudover understreger studiet, på baggrund af studieadministrative data i høj kvalitet, vigtigheden $\mathrm{i}$ at kontrollere for baggrundsfaktorer $\mathrm{i}$ forbindelse med fremtidig frafalds-

\footnotetext{
${ }^{9}$ Danmarks Evalueringsinstitut har siden 2016 undersøgt frafald på de videregående uddannelser, bl.a. ved brug af longitudinelt design (EVA, 2018b). Denne tilgang kan dog medføre problemer med panel mortalitet, dvs. at de studerende ikke svarer på opfølgende spørgeskemaer. Dette kan være særligt kritisk for studier af frafald, da det er sandsynligt at panel mortaliteten er korreleret med netop frafald.
} 
forskning og interne undersøgelser. Fx ved sammenligninger mellem studieretninger, institutioner etc. kan forskelle i studenteroptaget potentielt drive forskelle i frafaldsmønstre.

\section{Referencer}

Aarhus Universitet. (2016a). Arsager til frafald - rapport for Arts. Aarhus.

Aarhus Universitet. (2016b). Arsager til frafald - rapport for Science and Technology. Retrieved fromhttp://scitech.medarbejdere.au.dk/fileadmin/site_files/science.au.dk/files/ frafald/aarsager_til_frafald_ST_rapport.pdf

Aljohani, O. (2016a). A Comprehensive Review of the Major Studies and Theoretical Models of Student Retention in Higher Education. Higher Education Studies, 6(2), 1-18. https://doi.org/10.5539/hes.v6n2p1

Aljohani, O. (2016b). A Review of the Contemporary International Literature on Student Retention in Higher Education. International Journal of Education and Literacy Studies, 4(1). https://doi.org/10.7575/aiac.ijels.v.4n.1p.40

Astin, A. W. (1984). Student Involvement : A Developmental Theory for Higher Education. Journal of College Student Development, 40(5), 518-529. https://doi.org/10.1016/0263-

Bager-Elsborg, A., Herrmann, K. J., Troelsen, R. \& Ulriksen, L. (2019). Are leavers different from stayers? Uniped, 42(02), 139-156. https://doi.org/10.18261/issn.1893-8981-2019-02-03

Bean, J. P. (1990). Why students leave: Insights from research. In The Strategic Management of College Enrollments (pp. 147-169). San Francisco: Jossey-Bass.

Bean, J. P. \& Eaton, S. B. (2000). A psychological model of college student retention. In J. M. Braxton (Ed.), Reworking the departure puzzle: New theory and research on college student retention. (Vol. 1, pp. 48-61). Nashville: University of Vanberbilt Press.

Biggs, J. \& Tang, C. (2007). Teaching for Quality Learning at University Third Edition Teaching for Quality Learning at University (3rd ed.). New York: SRHE and Open University Press Imprint. https://doi.org/10.1016/j.ctcp.2007.09.003

Bourdieu, P. (1984). Homo Academicus. Stanford, California: Stanford University Press.

Bradburn, M. J., Clark, T. G., Love, S. B. \& Altman, D. G. (2003). Survival Analysis Part II: Multivariate data analysis - An introduction to concepts and methods. British Journal of Cancer, 89(3), 431-436. https://doi.org/10.1038/sj.bjc.6601119

Chimka, J. R., Reed-Rhoads, T. \& Barker, K. (2007). Proportional Hazards Models of Graduation. Journal of College Student Retention, 9(2), 221-232. https://doi.org/10.2190/CS.9.2.f

Cohen, J. (1988). Statistical power analysis for the behavioral sciences. Hillsdale, NJ: Lawrence Earlbaum Associates.

Cotton, D. R. E., Nash, T. \& Kneale, P. (2017). Supporting the retention of non-traditional students in Higher Education using a resilience framework. European Educational Research Journal, 16(1), 62-79. https://doi.org/10.1177/1474904116652629 
Cox, D. R. (1972). Regression Models and Life-Tables. Journal of the Royal Statistical Society. Series B (Methodological), 34(2), 187-220. https://doi.org/10.2307/2985181

Dex, S. (1995). The reliability of recall data: A literature review. Bulletin de Méthodologie Sociologique, 49(1), 58-89. https://doi.org/10.1177/075910639504900105

EVA. (2018a). Gymnasiale karakterers betydning for gennemførselstid på universiteterne. Retrieved from https://www.eva.dk/videregaaende-uddannelse/gymnasialekarakterers-betydning-frafald-paa-universiteterne

EVA. (2018b). Studievalg og frafald på de videregående uddannelser. Eva.Dk. Retrieved from https://www.eva.dk/videregaaende-uddannelse/studievalg-frafald-paavideregaaende-uddannelser

Hoff, J. \& Demirtas, M. (2009). Frafald blandt etniske minoritetsstuderende på universitetsuddannelserne i Danmark. Kbh.: Politiske Studier.

Højbjerg, K. \& Martinussen, M. (2015). "Er jeg akademiker nok?" - masseuniversitetets studenterkampe om legitim uddannelseskultur. Dansk Universitetspaedagogisk Tidsskrift, 10(18), 7-24. Retrieved from http://ojs.statsbiblioteket.dk/index.php/dut/article/view/15860/17968

Holm, P. \& Rasmussen, A. (2016). Kvote 2 optagelse - et middel til at: mindske frafald? - øge studieprogression? - matche den studerende bedre til uddannelsen?: Analyse af optag og efterfølgende studieforløb på veterinœruddannelsen. Retrieved from http://staticcuris.ku.dk/portal/files/156859287/Veterin_rmedicin_BA_og_KA_ver.7_final01032016. pdf

Holmegaard, H. T., Madsen, L. M. \& Ulriksen, L. (2017). Why should European higher education care about the retention of non-traditional students? European Educational Research Journal, 16(1), 3-11. https://doi.org/10.1177/1474904116683688

Jæger, M. M. \& Holm, A. (2007). Does parents' economic, cultural, and social capital explain the social class effect on educational attainment in the Scandinavian mobility regime? Social Science Research, 36(2), 719-744.

https://doi.org/10.1016/j.ssresearch.2006.11.003

Larsen, M. S., Kornbeck, K. P., Kristensen, R. M., Larsen, M. R. \& Sommersel, H. B. (2013). Dropout Phenomena at Universities: What is Dropout? Why does Dropout Occur? What Can be Done by the Universities to Prevent or Reduce it? A systematic review.

Larsen, U. (2000). Frafald og Studiemiljø. Aarhus. Retrieved from http://sr.au.dk/PDF/frafald/FFrapport.pdf

Lynch, J. M. \& Bishop-Clark, C. (1998). A Comparison of the Nontraditional Students' Experience on Traditional Versus Nontraditional College Campuses. Innovative Higher Education, 22(3), 217-229. https://doi.org/DOI: 10.1023/A:1025139510865

McQueen, H. (2009). Integration and regulation matters in educational transition: A theoretical critique of retention and attrition models. British Journal of Educational Studies, 57(1), 70-88. https://doi.org/10.1111/j.1467-8527.2008.00423.x 
Midtiby, H. S. \& Egemose, N. D. (2019). Matematiktest som prædiktor af ingeniørstuderendes studiesucces. Dansk Universitetspoedagogisk Tidsskrift, 14(26).

O'Neill, L. D., Christensen, M. K., Vonsild, M. C. \& Wallstedt, B. (2014). Program specific admission testing and dropout for sports science students : a prospective cohort study. Dansk Universitetspaedagogisk Tidsskrift, 9(17), 55-70.

O'Neill, L. D., Hartvigsen, J., Wallstedt, B., Korsholm, L. \& Eika, B. (2011). Medical school dropout - testing at admission versus selection by highest grades as predictors. Medical Education, 45(11), 1111-1120. https://doi.org/10.1111/j.13652923.2011.04057.x

O'Shea, S. (2016). Avoiding the manufacture of 'sameness': first-in-family students, cultural capital and the higher education environment. Higher Education, 72(1), 59-78. https://doi.org/10.1007/s10734-015-9938-y

Qvortrup, A., Smith, E., Lykkegaard, E. \& Rasmussen, F. (2018). Studiemiljø og frafald i videregående uddannelser: Betydningen af undervisning, faglig identifikation og social integration. Dansk Universitetspoedagogisk Tidsskrift, 13(25 SE-Videnskabelig artikel), 151-178. Retrieved from https://tidsskrift.dk/dut/article/view/97282

Reay, D., Crozier, G. \& Clayton, J. (2010). 'Fitting in' or 'standing out': working-class students in UK higher education. British Educational Research Journal, 36(1), 107-124. https://doi.org/10.1080/01411920902878925

Reimer, D. \& Pollak, R. (2010). Educational expansion and its consequences for vertical and horizontal inequalities in access to higher education in West Germany. European Sociological Review, 26(4), 415-430. https://doi.org/10.1093/esr/jcp029

Robinson, A. \& Laing, C. (2003). The withdrawal of non-traditional students: developing an explanatory model. Journal of Further and Higher Education, 27(2), 175-185. https://doi.org/10.1080/0309877032000065190

Sortkær, B. (2019). Feedback for everybody? Exploring the relationship between students' perceptions of feedback and students' socioeconomic status. British Educational Research Journal, 45(4), 717-735. https://doi.org/10.1002/berj.3522

Spady, W. G. (1970). Dropouts from higher education: An interdisciplinary review and synthesis. Interchange, 1(1), 64-85. https://doi.org/10.1007/BF02214313

Thingholm, H. B., Reimer, D., Keiding, T. B., Due, J. L. \& Smith, E. (2016). Navigating in Higher Education - NiHE. AU Library Scholarly Publishing Services. Retrieved from http://edu.au.dk/fileadmin/edu/Udgivelser/E-boeger/Ebog__Navigating_in_Higher_Education_-_NiHE_-_2016_-_final.pdf

Thomsen, J. P. (2015). Maintaining inequality effectively? Access to higher education programmes in a universalist welfare state in periods of educational expansion 19842010. European Sociological Review, 31(6), 683-696. https://doi.org/10.1093/esr/jcv067

Thomsen, J. P., Munk, M. D., Eiberg-Madsen, M. \& Hansen, G. I. (2013). The Educational Strategies of Danish University Students from Professional and Working-Class Backgrounds. Comparative Education Review, 57(3), 457-480. https://doi.org/10.1086/670806 
Tinto, V. (1975). Dropout from Higher Education: A Theoretical Synthesis of Recent Research. Review of Educational Research, 45(1 (Winter)), 89-125.

Tinto, V. (2000). Linking learning and leaving. In J. M. Braxton (Ed.), Reworking the Student Departure Puzzle (pp. 81-94). Nashville: Vanderbilt University Press.

Tinto, V. (2012). Enhancing student success: Taking the classroom success seriously. The International Journal of the First Year in Higher Education, 3(1), 1-8. https://doi.org/10.5204/intjfyhe.v2i1.119

Troelsen, R. (2011). Frafald på de videregående uddannelser - hvad ved vi om årsagerne? Dansk Universitetspoedagogisk Tidsskrift, 6(10), 37-44.

Troelsen, R. \& Laursen, P. F. (2014). Is Drop-out from University Dependent on National Culture and Policy? The Case of Denmark. European Journal of Education, 49(4), 484496. https://doi.org/10.1111/ejed.12094

Trow, M. (1972). The expansion and transformation of higher education. International Review of Education, 18(1), 61-84. https://doi.org/10.1007/BF01450272

Willett, J. B. \& Singer, J. D. (1991). From Whether to When: New Methods for Studying Student Dropout and Teacher Attrition. Review of Educational Research, 61(4), 407-450. https://doi.org/10.3102/00346543061004407 